\title{
GENDER PAY GAP: A MACRO PERSPECTIVE
}

Akiko Terada-Hagiwara, Shiela F. Camingue-Romance, and Joseph E. Zveglich, Jr.

NO. 538

March 2018
ADB ECONOMICS WORKING PAPER SERIES 
ADB Economics Working Paper Series

\section{Gender Pay Gap: A Macro Perspective}

Akiko Terada-Hagiwara, Shiela F. CamingueRomance, and Joseph E. Zveglich, Jr.

No. 538 | March 2018
Akiko Terada-Hagiwara (ahagiwara@adb.org) is a principal economist at the East Asia Department. Shiela F. Camingue-Romance (scamingue@adb.org) is an economics officer and Joseph E. Zveglich, Jr. (jezveglich@adb.org) is a director, both at the Economic Research and Regional Cooperation Department of the Asian Development Bank.

This paper was initially prepared as background material for the Asian Development Outlook 2015 Update theme on Empowering Women, Energizing Asia. The authors are indebted to Shangjin Wei and participants of the Asian Development Outlook workshop, as well as Joanne Yoong and participants of the 12th International Conference of the Western Economic Association International for their insightful comments. The remaining errors are those of the authors. 
(C) 2018 Asian Development Bank

6 ADB Avenue, Mandaluyong City, 1550 Metro Manila, Philippines

Tel +632632 4444; Fax +6326362444

www.adb.org

Some rights reserved. Published in 2018.

ISSN 2313-6537 (print), 2313-6545 (electronic)

Publication Stock No. WPS189255-2

DOI: http://dx.doi.org/10.22617/WPS189255-2

The views expressed in this publication are those of the authors and do not necessarily reflect the views and policies of the Asian Development Bank (ADB) or its Board of Governors or the governments they represent.

ADB does not guarantee the accuracy of the data included in this publication and accepts no responsibility for any consequence of their use. The mention of specific companies or products of manufacturers does not imply that they are endorsed or recommended by ADB in preference to others of a similar nature that are not mentioned.

By making any designation of or reference to a particular territory or geographic area, or by using the term "country" in this document, $A D B$ does not intend to make any judgments as to the legal or other status of any territory or area.

This work is available under the Creative Commons Attribution 3.0 IGO license (CC BY 3.0 IGO)

https://creativecommons.org/licenses/by/3.0/igo/. By using the content of this publication, you agree to be bound by the terms of this license. For attribution, translations, adaptations, and permissions, please read the provisions and terms of use at https://www.adb.org/terms-use\#openaccess

This CC license does not apply to non-ADB copyright materials in this publication. If the material is attributed to another source, please contact the copyright owner or publisher of that source for permission to reproduce it. $\mathrm{ADB}$ cannot be held liable for any claims that arise as a result of your use of the material.

Please contact pubsmarketing@adb.org if you have questions or comments with respect to content, or if you wish to obtain copyright permission for your intended use that does not fall within these terms, or for permission to use the ADB logo.

Notes:

In this publication, “\$” refers to US dollars.

Corrigenda to ADB publications may be found at http://www.adb.org/publications/corrigenda 


\section{CONTENTS}

FIGURES

ABSTRACT $v V$

$\begin{array}{ll}\text { I. INTRODUCTION } & 1\end{array}$

II. THEORETICAL AND EMPIRICAL LITERATURE 2

III. TREND ACROSS COUNTRIES 3
A. The Wage Data

B. Trends in Gender Wage Gap 3

IV. $\quad$ EMPIRICAL INVESTIGATION OF THE GENDER WAGE GAP 6
A. Estimation Framework
6

B. Data Descriptions

V. EMPIRICAL RESULTS 11

A. Full Sample Results $\quad 11$

B. Does Level of Development Matter?

VI. $\quad$ CONCLUSION AND POLICY IMPLICATIONS 17

$\begin{array}{ll}\text { APPENDIX } & 19\end{array}$

$\begin{array}{ll}\text { REFERENCES } & 21\end{array}$ 


\section{TABLES AND FIGURES}

\section{TABLES}

1 Descriptive Statistics

2 List of Economies Included in the Final Sample

3 Regression Results for the Full Sample

4 Regression Results: Developed versus Developing Economies

\section{FIGURES}

$1 \quad$ Wage Ratio and Gross Domestic Product per Worker, $\quad 4$

2 Gender Wage Gap Variations, Developing versus Developed Economies 5

3 Wage Ratio Developing versus Developed Economies 


\begin{abstract}
This paper examines the factors influencing the gender wage gap by using an unbalanced crosscountry aggregated panel data set for a sample covering 53 economies for the period 1995-2010. Using robust estimators proposed by Lewbel (2012) to correct for heterogeneity and endogeneity, results suggest that a higher female share in the industry sector tends to widen the gender wage gap regardless of a country's development stage. While having more children widens the gender wage gap, as expected, the effect is only statistically significant for developing countries. In developed countries, more labor force participation by women seems to narrow the gender wage gap, probably due to the number of female labor market entrants taking up higher-paying service sector jobs. For developing countries, closing the gender gaps in labor force participation and education is not sufficient to achieve gender wage parity. Higher-paying jobs should be created by developing the service sector in these economies.
\end{abstract}

Key words: developing countries, gender, instrumental variables, panel data, wage gap

JEL codes: E24, J16, J31 


\section{INTRODUCTION}

The male-female wage gap is a persistent global phenomenon. In the Organisation for Economic Cooperation and Development (OECD) countries, for example, women still earn 84\% of men's hourly earnings on average (OECD 2002). Country studies consistently show that the wage gap remains even after controlling for gender differences in qualifications and type of work. Moreover, progress in closing the gap is sporadic. In the United States (US), the gap narrowed in the 1980s after a stable period following the 1960s (Blau and Kahn 2000), but wage convergence then slowed with the gap remaining almost constant since the early 1990s (Blau and Kahn 2006). Similar findings are presented for other advanced economies, such as Sweden's (Edin and Richardson 2002) and Denmark's (Datta Gupta, Oaxaca, and Smith 2006). As the wage gap may discourage women from investing in human capital or participating in the labor market-essentially creating a vicious cycle that hinders women's future progress toward equality-understanding its root cause is important.

Gender gap studies using micro data are plentiful for both developed and developing countries, though data limitations make cross-country comparisons difficult. Wage and earning indicators tend to be developed based on country- (or region-) specific criteria that are not always comparable. For example, Blau and Kahn (2003) conducted a study looking for international comparison in gender pay gap, but their sample is limited mostly to developed economies. Weichselbaumer and Winter-Ebmer (2005) use meta-analysis to generalize the results from more than 260 country studies. We contribute to this strand of the literature by augmenting wage data compiled by the International Labour Organization (ILO) to create a data set of 53 economies during 1995-2011. Taking advantage of the panel aspects of the data, this paper models cross-country gender

wage gap differences by both micro and macro-level factors. We use robust estimators following Lewbel (2012) to address heterogeneity and endogeneity issues. Further, the paper investigates if the factors influencing the gender gap behave differently across developed and developing countries to highlight developing country-specific issues and policy implications.

Results suggest that both micro and macro factors affect the gender wage gap. In particular, higher female share in the industry sector matters in widening the female workers' wage below their male counterparts. This result holds for both developing and developed countries. Meanwhile, having more children would result in widening the gender wage gap, as expected, but we find that this is significant only in developing countries. Further, for developing countries, we find that more labor market participation or more years in schooling by women alone would not lead to narrow the gender wage gap. In fact, the gender wage gap could widen as more women are recruited for low-paying jobs in developing countries. Higher-paying jobs should be created such as through developing the service sector in these economies. In developed countries, on the other hand, more labor force participation by women does seem to narrow the gender wage gap, probably due to more organized labor union made available regardless of gender and female workers taking up higher-paying service sector jobs.

The remainder of the paper is organized as follows. The next section reviews the theoretical and empirical literature analyzing gender wage differences. Section III describes the wage data set used in this paper, and discusses trends in gender wage gaps across countries and regions in this date. The fourth section presents the empirical framework, estimation strategy, and nonwage variables used in the analysis. The fifth section presents the empirical results. The final section concludes with some thoughts on policy implications. 


\section{THEORETICAL AND EMPIRICAL LITERATURE}

The seminal work by Mincer (1974) utilizes a model of investment in human capital, and claims that the wage gap is predominantly driven by the gender productivity gap. Its empirical investigation is conducted through estimating a linear equation of wage as a function of education and variables capturing experience. In this scenario, the wage gap between different genders arises because of the difference between investments in individual human capital.

A large body of empirical literature using household- or individual-level data confirms the claim using various proxy variables. An important feature of the gender wage gap is its evolution over the life cycle as a function of labor market experience. The gender wage gap is relatively small when workers are young, and it increases with workers' age as women, on average, tend to drop out of the labor market at a younger age. In contrast, the gender wage gap for workers who work continuously full time decreases with age. An increase in aggregate productivity in professional occupations is found to play a major role in the increase in women's labor force participation, professional-occupation representation, and hours worked. Labor market experience is considered as one of the most important ones (Gayle and Golan 2011). Variants of explanatory variables are also used to capture the so-called family gap: women who marry and have children experience a wider wage gap than unmarried women with no children (Ginther 2004, Waldfogel 1998, and Winder 2004); higher levels of occupational segregation, i.e., men and women are allocated gender-specific categories for occupations that differ in wages paid (Meyersson Milgrom, Petersen, and Snarland 2001); and more self-selection of women into sectors with lower wage growth (Rosholm and Smith 1996).

The literature developed as Becker (1985) brings the increasing returns to specialization and gains from a division of labor into the picture of the gender wage gap. Becker (1985) explains gender wage gap as a Pareto efficient outcome through the intrahousehold decision on division of labor. Further extensions have been made on the time allocation between genders following Becker's work. A significant extension is the introduction of a framework, where households operate with both spouses providing time inputs instead of only one person earning wages in the labor market. Wage gap endogenously arises after selective time allocation in this framework. The major difference between earlier works, such as Becker and those that take into account the time allocation, is that the expected gender wage gap or some forms of belief in the wage gap is a determining factor in the time allocation, labor participation, and hence wages. In studies such as Chichilinsky and Frederiksen (2008) and Frederiksen (2006), beliefs about the inferiority of women's productivity are shown to be self-fulfilling, and, in these studies, addressing endogeneity is even more important in estimating a reduced form equation.

While the productivity factors at individual and household levels have been the primary factors driving the gender wage gap variation, existing literature also identifies macro-level factors that can explain cross-country wage gap variation. Those include factors such as family-friendly policies that may have adverse effects on female wages (Datta Gupta, Oaxaca, and Smith 2006). Also, industry structure and its demand mix for particular skill sets are important. Olivetti and Petrongolo (2014) show that differences in the service share are important determinants of the cross-country variation in women's labor market outcomes. Blau and Kahn (2003) look at the role of wage-setting institution and unionization, and find that the extent of collective-bargaining coverage in a country is significantly negatively related to the gender wage gap.'

\footnotetext{
1 To a lesser extent, demographic changes, home-production technology, and/or discrimination are also cited as possible
} factors in the literature (Blackaby, Booth, and Frank 2005; and Blau and Kahn 2006). 


\section{TREND ACROSS COUNTRIES}

\section{A. The Wage Data}

The wage data used in this paper are taken from the Global Wage Report 2012 of the ILO, which publishes nominal and real wage indicators, minimum wages, and wage inequality indicators. The ILO data is augmented to achieve a sample of 53 economies for the period 1995-2010. The list of countries included in the sample is in Table 2.

In this paper, the gender wage gap is calculated as the ratio of female to male gross average nominal monthly wages. The wage data is defined as total gross remuneration, including regular bonuses received during a specified period by all employees (wage earners and salaried employees), full-time workers, ${ }^{2}$ and other types of employees ${ }^{3}$ (ILO 2012). The wage data are converted to monthly, either from annual, biannual, quarterly, weekly, daily, or hourly, data regardless of the wage calculation coverage. ${ }^{4}$ The wage data covers all sectors, manufacturing and services, both public and private sectors; except for a small fraction of the total sample where the sample includes only earnings by workers in the private sector. For some countries, the wage data are based on the national average, while, in some, this pertains only to wages of workers employed in urban areas.

\section{B. Trends in Gender Wage Gap}

For the 53 economies with comparable data, the wage ratio, measured as the log of average female to male monthly nominal wage, is mostly negative-female workers receive lower wages than male workers (Figure 1). This is true in most developed ${ }^{5}$ and developing economies. ${ }^{6}$ In 2010, average female workers are paid about 17 percentage points less than their male counterparts in the world. This is an improvement from an estimated 22 percentage points difference in 2005 and 24 percentage points in 2000.

2 In some cases, "full time" refers to employees working between 30 and 40 hours per week, or more than 8 hours in a day, whereas in some, the data pertain to those employees whose working hours account for over $90 \%$ of total working hours in that industry.

3 For example, production and nonsupervisory employees in the case of the US, nonmanual workers in Sweden, and nonsupervisory employees in Indonesia.

4 There are cases where a country's wage bill is divided by the absolute number of employees, whereas in other cases, an adjustment is made for differences in the number of hours worked between employees to get the full-time equivalent. An example would be part-time workers, in which case, the rates are converted to their full-time equivalent; and part-year workers, in which case, their wages are calculated with a weight corresponding to the proportion of the year that they were counted as employees (ILO Global Wage Database 2012).

5 Developed economies here refers to high-income OECD economies, based on the July 2016 definition and groupings by the World Bank. https://datahelpdesk.worldbank.org/knowledgebase/articles/906519-world-bank-country-and-lendinggroups. The Republic of Korea has been reclassified as a developing country per the definition of the Asian Development Bank; while Mexico and Turkey are reclassified as nondeveloped countries, as both are upper-middle-income countries as of July 2016.

6 While important, the distinction between developing and nondeveloping Asian countries is not discussed in detail. 
While the mean values all cluster below zero, female workers in developing countries are surprisingly paid more than their male counterparts compared with female workers in developed economies. Female workers in developed countries earn only about $75 \%$ of their male counterparts, whereas it is about $83 \%$ in developing countries during the period 2005-2010. The difference can be attributed to the distinctive variations in gender wage gap among developing countries (Figure 2). Female workers are paid the highest in Southeast Asia, and the Middle East and North Africa (MENA) region, at more than what their male workers receive, followed by those in upper-middle-income OECD countries and non-OECD Europe. The least paid can be found in Central Asia and East Asia, though the latter pertains only to data for Taipei,China and the Republic Korea. The gender wage disparity issue in the Republic of Korea is well-documented and the theoretical underpinnings that explain its occurrence abound.

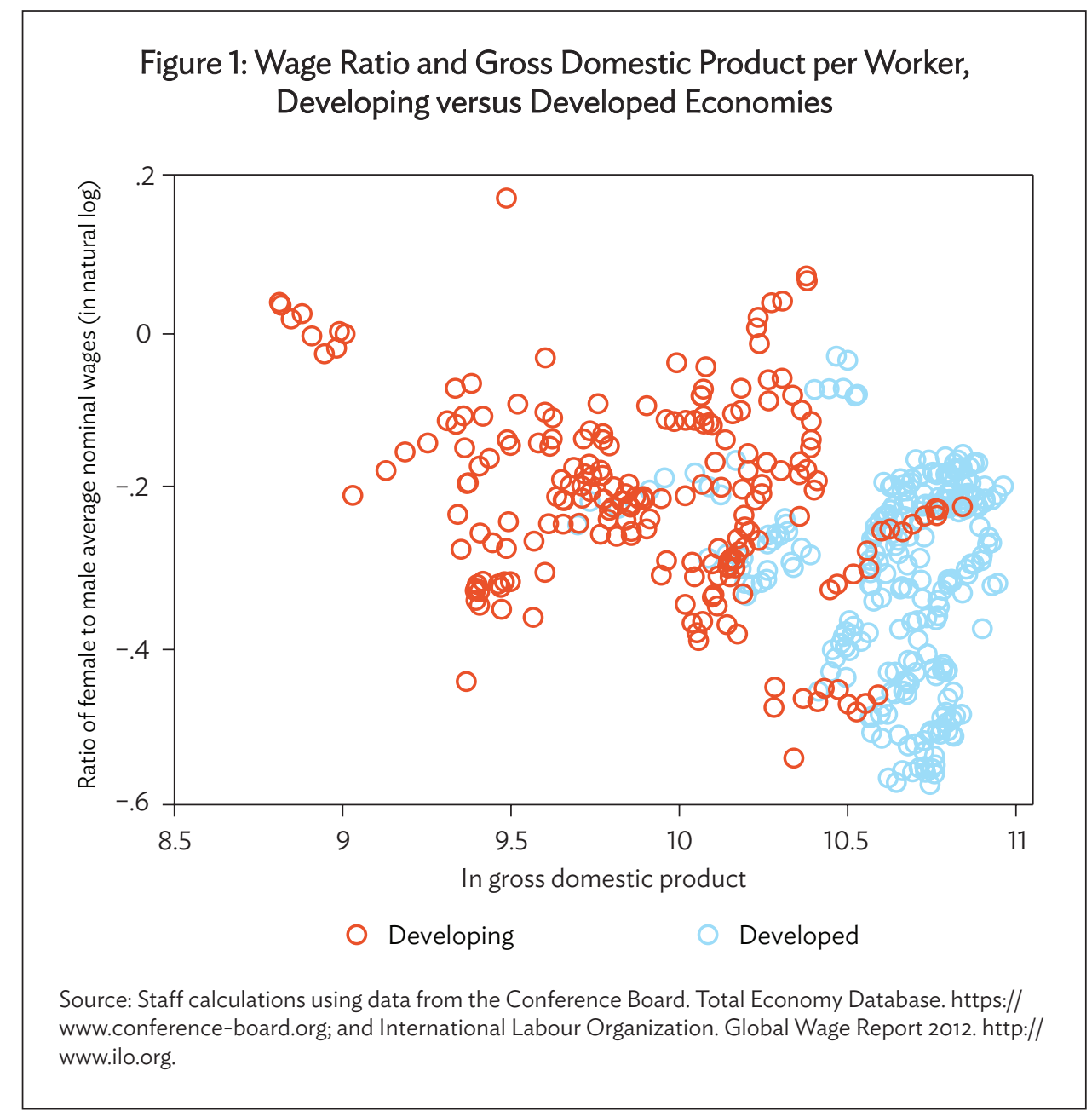


Figure 2: Gender Wage Gap Variations, Developing versus Developed Economies

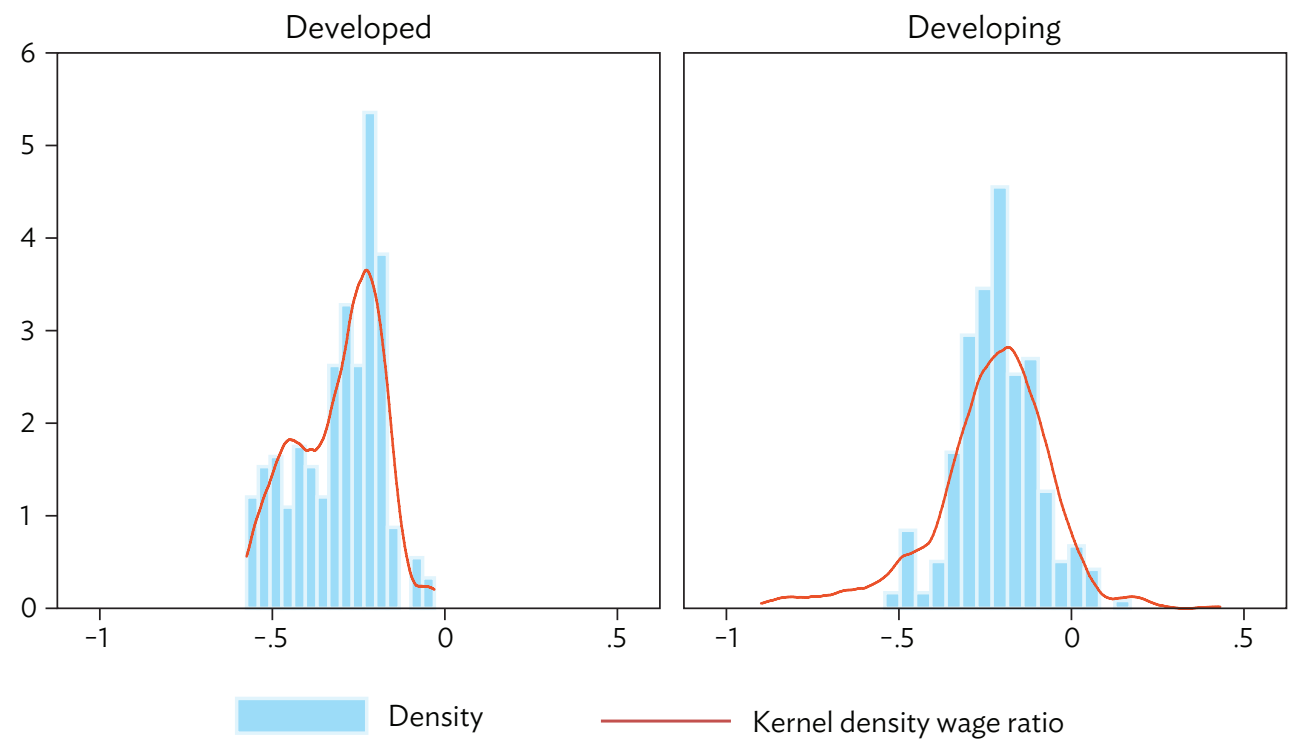

Notes: kernel = epanechnikov; bandwidth: 0.03521392 (developed) and 0.03713287 (developing).

Source: Staff calculations using data from International Labour Organization. Global Wage Report 2012.: http://www.ilo.org.

In addition to the large wage gap, what is more worrisome is the persistency of this gap. This is true for both developed and developing countries. Wage gap narrowed globally, but very slowly. In the US, ever since women entered the labor force, the gender wage gap has been closing. The gap narrowed in the 1980s after a stable period following the 1960s (Blau and Kahn 2000). Since then the convergence of male and female wages has slowed. The gender wage gap has remained almost constant since the early 1990s (Blau and Kahn 2006). Similar findings are presented for other advanced economies, such as Sweden's (Edin and Richardson 2002) and Denmark's (Datta Gupta, Oaxaca, and Smith 2006).

In developing countries included in the sample, the trend varies across regions. In Latin America, the gap widened a bit from $81 \%$ in the 1996-2000 period to $79 \%$ in $2001-2005$ then narrowed to 82\% in 2006-2010, while it consistently lessened since 1996-2000 in developing Asia, non-OECD Europe, MENA, and upper-middle-income OECD. The gap narrowed the most in developing Asia and MENA in 2006-2010, improving by 16\% since 1996-2000, while it stagnated in Latin America, improving only by $1.3 \%$ during the same period. In the rest of the developing economies, the gap narrowed by about $8 \%$.

However, the narrowing of the gap in developing countries since the 1990s is slightly faster than the rate of convergence in developed countries (Figure 3). The gap in developing countries narrowed from 77\% during the period $1996-2000$ to $80 \%$ in 2001-2005 and then to 84\% in 20062010, with a noticeable drop during the global financial crisis in 2008-2009; while the gap in developed countries during the three 5-year periods barely moved, staying mostly at around $73 \%$ during the first two periods and improving only slightly to $75 \%$ in $2006-2010$. This is likely due to wage 
reversals in most developed countries from the period 1996-2000 to 2001-2005. Wage reversals continued for a small number of countries in 2006-2010, likely due to the economic and social fallout from the global financial crisis, but the changes have been generally modest, at less than $1 \%$.

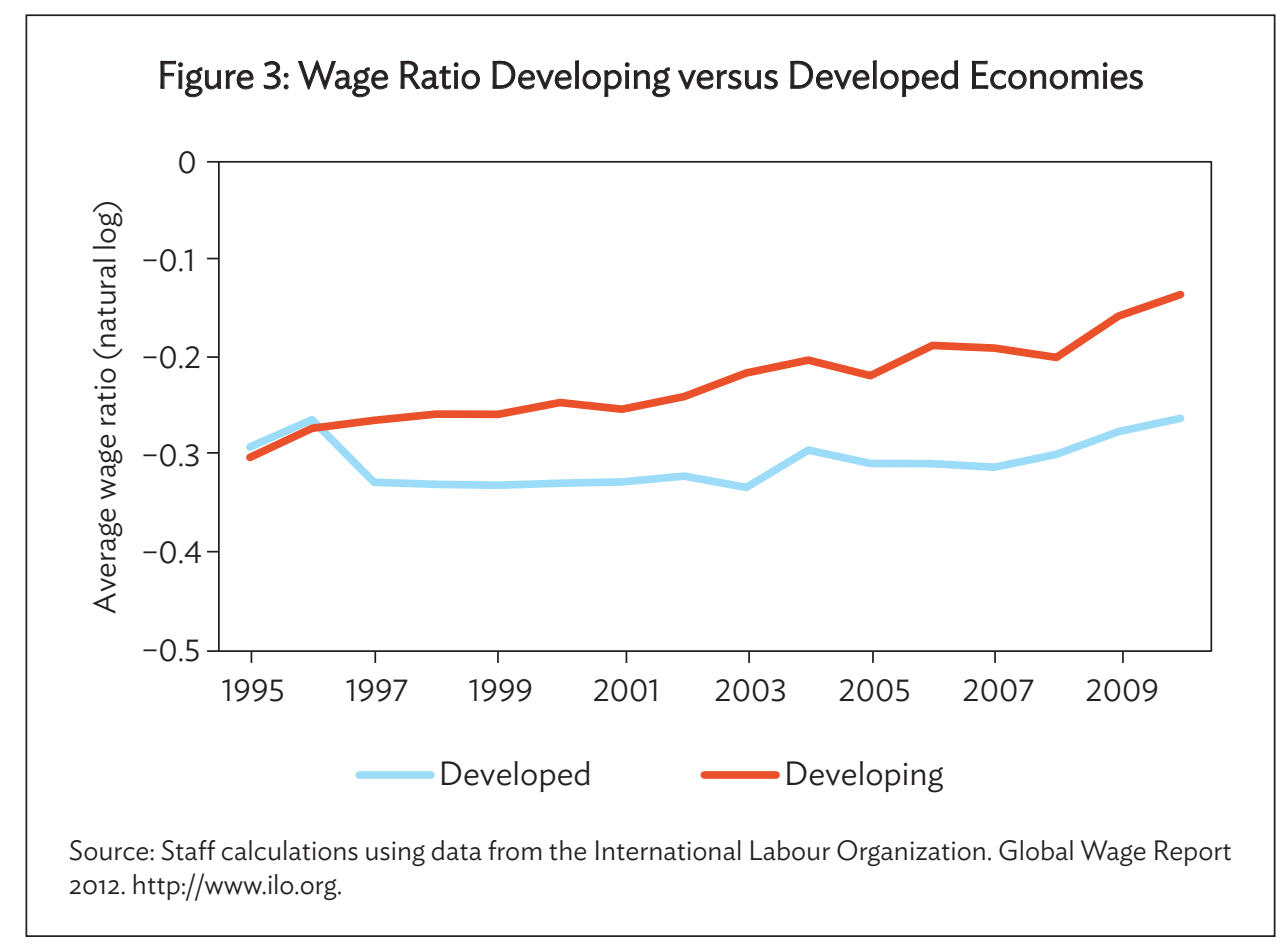

\section{EMPIRICAL INVESTIGATION OF THE GENDER WAGE GAP}

\section{A. Estimation Framework}

The approach we take to understanding the macro-level gender pay gaps is analogous to the microlevel Oaxaca-Blinder wage gap decomposition (Oaxaca 1973 and Blinder 1973). That decomposition relates gender pay differences to male-female differences in observable productivity characteristicssuch as education, experience, occupation, industry, and location-and a residual. The market returns to observables are derived from estimated human capital earnings functions using micro data on workers from household or firm surveys. The residual wage gap captures the portion from compensation differences between the sexes for the same observable characteristics. While this residual is often attributed to discrimination, it also encompasses the effect of unmeasured or omitted characteristics that affect worker productivity.

However, the focus of this study is not measuring the extent of discrimination, but rather gauging how macro-level pay gaps relate to gender differences in aggregate productivity characteristics. Using the logic of the Oaxaca-Blinder decomposition, let $\Gamma_{c t}$ denote some measure of the gender earnings gap for country $c$ at time $t$ and $\pi_{j c t}$ the $j$ th observable aggregate productivity difference. The relationship to be estimated takes the following form:

$$
\Gamma_{c t}=\sum_{j=1}^{J} \beta_{j} \pi_{j c t}+\delta_{c}+\tau_{t}+\varepsilon_{c t}
$$


where $\delta_{c}$ are country fixed effects, $\tau_{t}$ are year dummies, and $\varepsilon_{c t}$ are the error terms. The country fixed effects isolate the impacts of time-invariant country-specific factors from those due to country differences in gender gaps in productivity characteristics. Similarly, the year dummies isolate business cycle effects not transmitted through fluctuations in the observed productivity differences.

A quick look at the unconditional means of gender wage gap suggests that the gap is still significant. The usual suspects for observable characteristics that would drive the gap include (i) longer work hours associated with male workers widening the gap (Gayle and Golan 2011); and (ii) married female workers with child-rearing and childbearing responsibilities receiving lower wage (Ginther 2004, Waldfogel 1998, and Winder 2004). Female workers tend to be younger relative to male workers across the countries, which indicates a shorter work experience widening the gap as well. Average years of schooling are included to capture productivity differences. Female concentration in lower-paying industry or occupation can widen the gap (Meyersson Milgrom, Petersen, and Snarland 2001). The lower-paying industries, however, vary depending on the industry mix and the stage of development of a country. Expected impacts, therefore, are ambiguous.

Cross-sectional regression analyses of wage gaps require attention to data problems such as self-selection, heterogeneity, and endogeneity. Self-selection exists if the employed workers do not form a random subgroup of the sampled population, but differ systematically from those who are unemployed. However, since the wage data used in this paper are at the country level, this issue becomes less of a concern. The heterogeneity-biased estimates of the factors affecting wage rate may occur if wage per se is related to unobserved individual characteristics, such as motives or skills, that are, in turn, correlated with observed independent variables. Endogeneity becomes a problem if explanatory variables, such as public sector employment or educational choices, are not given exogenously but subject to an individual's decision and, hence, also at risk of being correlated with unobserved factors. Their impact on the wage rate is, therefore, likely to be biased if not modeled properly (Beblo et al. 2003).

To address these issues, multiple estimation methodologies are used as well as simpler estimators. This paper contributes to the literature by applying a rigorous methodology suggested by Lewbel (2012), which can take account of the methodological issues mentioned. This methodology implements the estimator that uses heterogeneity to do instrumental variables estimation when no or limited instruments are available.

\section{B. Data Descriptions}

Table 1 provides a descriptive statistic of the data used in the study. As discussed earlier, the gender wage gap is calculated as the ratio of female to male gross average nominal monthly wages. It is defined as total gross remuneration, including regular bonuses, received during a specified period by all employees (either wage earners or salaried employees), full-time workers, and other types of employees.

A wage ratio less than or greater than 1 indicates the presence of a gap, while a ratio of 1 indicates parity. A ratio less than 1 means women are paid lower than men, while a ratio greater than 1 indicates the opposite. Based on the sample, the average ratio of female monthly earnings relative to male is 0.78 , indicating that women are paid lower than men, but there are also countries where men are paid lower than women. Women are mostly in the service sector compared with other industries, and there seems to be high labor force participation by young female workers. Female participation in part-time jobs are much higher relative to men. 
Table 1: Descriptive Statistics

\begin{tabular}{|c|c|c|c|c|c|}
\hline Variable & Observations & Mean & $\begin{array}{l}\text { Standard } \\
\text { Deviation }\end{array}$ & Minimum & Maximum \\
\hline $\begin{array}{l}\text { Ratio of female to male average } \\
\text { nominal monthly wages (Wage } \\
\text { gap, W) }\end{array}$ & 536 & 0.78 & 0.10 & 0.56 & 1.19 \\
\hline $\begin{array}{l}\text { Ratio of share of total female } \\
\text { employment working part time to } \\
\text { share of total male employment } \\
\text { working part time (PT) }\end{array}$ & 536 & 3.32 & 2.55 & 0.40 & 19.85 \\
\hline $\begin{array}{l}\text { Ratio of share of female workers } \\
\text { in services to share of male } \\
\text { workers in services } \\
\text { (servemployratioln) }\end{array}$ & 536 & 1.54 & 0.44 & 0.71 & 3.98 \\
\hline $\begin{array}{l}\text { Ratio of share of female workers } \\
\text { in industry to share of male } \\
\text { workers in industry } \\
\text { (indemployratioln) }\end{array}$ & 536 & 0.49 & 0.31 & 0.17 & 2.10 \\
\hline $\begin{array}{l}\text { Ratio of share of female workers } \\
\text { in agriculture to share of male } \\
\text { workers in agriculture } \\
\text { (agriemployratioln) }\end{array}$ & 536 & 0.59 & 0.40 & 0.07 & 2.45 \\
\hline $\begin{array}{l}\text { Fertility rate (births per women) } \\
\text { (FERT) }\end{array}$ & 536 & 0.64 & 0.31 & -0.11 & 1.53 \\
\hline $\begin{array}{l}\text { Ratio of share of female workers } \\
\text { that are young to share of male } \\
\text { workers that are young (lfagegap) }\end{array}$ & 536 & 1.05 & 0.22 & 0.59 & 2.12 \\
\hline $\begin{array}{l}\text { Ratio of female labor force } \\
\text { participation rate to male labor } \\
\text { force participation rate } \\
\text { (LFPRratioln) }\end{array}$ & 536 & 0.79 & 0.26 & 0.18 & 2.17 \\
\hline $\begin{array}{l}\text { Ratio of female to male years of } \\
\text { schooling (yrschln) }\end{array}$ & 536 & 0.95 & 0.07 & 0.70 & 1.07 \\
\hline
\end{tabular}

Sources: Staff calculations using data from the World Bank, World Development Indicators online database.

http://databank.worldbank.org/data/home.aspx; International Labour Organization. Global Wage Report 2012. http://www.ilo.org; Barro, Robert, and Jong-Wha Lee. 2013. “A New Data Set of Educational Attainment in the World, 1950-2010.” Journal of Development Economics 104: 184-98 (August 2014 Update). http://www.barrolee.com; Philippine Statistics Authority, Labor Force Survey; and DGBAS, Manpower Survey Results.

The wage data generally pertains to those earned by full-time workers. But, for some countries in this study (full list in Table 2), the wage data refers to earnings by part-time workers at their full-time equivalent. Because wages by part-time workers converted to their full-time equivalent are likely to affect average earnings, we introduced part-time employment as an additional variable. The use of parttime employment in this study is based on (i) its rapid growth in the past few decades across economies, (ii) increased participation by female workers, and (iii) policies that attempt to raise labor market flexibility in reaction to changes in the work organization within industries and to the rapid rise of the service sector. Female part-time employment has been observed to be positively correlated with gender wage gap in some economies, and the gap tends to be wider in countries where female part-time employment is higher (see, for example, Matteazzi, Pailhé, and Solaz 2013). Part-time jobs are generally lower paid. Hence, an increase in the number of women participating in part-time jobs widens the gap. 
There are cases, however, where total pay for part-time work is just as well as those working full time. To analyze if the overrepresentation of women in jobs other than full-time increases wage disparity on a wider scale, we used part-time employment data for a set of 53 economies, calculated as a ratio to total employment and covers individuals whose total working hours are less than full time. Then, we calculated the ratio of female to male part-time employment.

Table 2: List of Economies Included in the Final Sample

\begin{tabular}{ll}
\hline Developed & Developing \\
\hline Australia (2001-2008) & Argentina (1998-2003, 2005-2010) \\
Austria (1997-2010) & Armenia (2008) \\
Belgium (1999-2009) & Bahrain (2004) \\
Canada (1997-2008) & Brazil (2001-2009) \\
Czech Republic (2005-2010) & Bulgaria (2001-2010) \\
Denmark (2009-2010) & Colombia (2000, 2002-2010) \\
Estonia (2005-2008) & Costa Rica (1995-2010) \\
Finland (1995-2010) & Croatia (2003-2010) \\
France (1998-2009) & Cyprus (1999-2009) \\
Germany (1995-2010) & Ecuador (1995, 1998-2001, 2003-2010) \\
Iceland (1998-2010) & El Salvador (2000-2002, 2004-2010) \\
Ireland (2003, 2006-2007) & Honduras (1995-1999, 2001-2003) \\
Israel (1995-2009) & Latvia (2004-2010) \\
Japan (2002-2010) & Lithuania (2000-2010) \\
Luxembourg (1995-2010) & Malta (2000, 2003-2010) \\
The Netherlands (2006-2010) & Mexico (1995-2010) \\
New Zealand (1998-2009) & Panama (1995-2003, 2005-2010) \\
Norway (1997-2010) & Paraguay (1995, 1997, 1999, 2000, 2002-2008) \\
Poland (1997-1999,2001, 2002, 2004, 2006, 2008, 2010) & Peru (2001-2009) \\
Portugal (1995-2000,2002-2009) & Philippines (2001-2009) \\
Slovakia (2005-2010 & Republic of Korea (1995-2006) \\
Slovenia (2004-2010) & Romania (2003-2010) \\
Spain (2004-2010) & Tyrian Arab Republic (2006-2010) \\
Sweden (1995-2010) & Taipei,China (1995-2010) \\
Switzerland (1996, 1998, 2000, 2002, 2004, 2006, 2008) \\
2010) & Uruguay (2000-2003, 2005-2007) \\
United Kingdom (1997-2010) & Venezuela, Bolivarian Republic of (1995-2010) \\
\hline & \\
\hline
\end{tabular}

\footnotetext{
, = data break.
}

Notes: Developed economies here refers to high-income OECD economies, based on the July 2016 definition and groupings by the World Bank. https://datahelpdesk.worldbank.org/knowledgebase/articles/906519-world-bank-country-and-lending-groups.

For this study, the Republic of Korea is classified as a developing economy based on the definition of the Asian Development Bank.

Sources: Staff calculations using data from the World Bank, World Development Indicators online database.

http://databank.worldbank.org/data/home.aspx; International Labour Organization. Global Wage Report 2012. http://www.ilo.org; Barro,

Robert, and Jong-Wha Lee. 2013. “A New Data Set of Educational Attainment in the World, 1950-2010.” Journal of Development Economics 104: 184-98 (August 2014 Update). http://www.barrolee.com; Philippine Statistics Authority, Labor Force Survey; and DGBAS, Manpower Survey Results. 
ILO explains, however, that there is no agreed international definition as to the minimum number of hours in a week that constitute full-time work. Hence, the dividing line is determined either on a country-by-country basis or using special estimations. Dividing lines are typically somewhere between 30 and 40 hours a week (ILO 2014). Thus, people who work for, say, 35 hours or more per week may be considered full-time workers, and those working less than 35 hours part-time workers. This can be a source of bias, especially when the share of part-time employment converted to full-time work is high, skewing mean wages either upwards or downwards. In the sample, the mean ratio of female to male part-time employment is 3.4, and this ratio is highest in Luxembourg at 19.8 and Austria at 9.5, and in MENA region at 3.9. In the case of Luxembourg, female part-time employment ratio is high because part-time workers can perform overtime work, which increases take-home pay, thus, encouraging more women to take part-time jobs, while balancing family and work life. Moreover, the country has high state allocations for childcare; and the marginal tax rate for working women in the household, however low, is based on the wage of the husband, discouraging women to work full time. Another potential source of bias is the coverage or work location of workers. For instance, in some European Union countries, the labor force survey covers the total population residing in other member states, but excludes foreign residents working in the country; while in others foreign workers who have stayed in the country for at least 1 year are included. This can make a sizable difference in small countries with relatively high cross-border workers, such as Luxembourg. In other countries, such as the Philippines, labor force surveys exclude residents working in other countries.

Occupation segregation also plays an important role in the disparity (Blau and Kahn 2007; and Meyersson Milgrom, Petersen, and Snarland 2001). But, due to the lack of good data on occupations by gender for the sample countries looked at, it is difficult to determine whether the degree of movement of women through the ranks is sufficient to confirm or disprove beliefs that women are paid lower than men. To capture wage disparity across occupations, we used sector segregation, measured as the proportion of women to men working in a specific sector (agriculture, industry, or services), to determine if increased participation by women in traditionally low-paying or women-dominated industries or sectors widens the gap. The differences in wages across major sectors can provide us an idea as to the degree of occupation segregation and the role it plays on gender pay gap. Some researchers find that there is a clear wage penalty for working in female-dominated occupations or industries than in maledominated ones (see, for example, Hegewisch and Hartmann 2014, and Baron and Clark 2008).

This paper also accounts for the impact of differences in years of schooling or educational participation on the wage disparity. The examination of female participation in education from primary to advanced level of education provides an idea where, in the female worker's cycle, the wage gap is more disproportionate. While education per se does not close the gender pay gap, greater education increases overall earnings of both men and women. Generally, the gender pay gap widens for persons with advanced degrees compared with people with high school or college education. To check how this varies across gender and/or affects the gender pay gap, we looked at the years of schooling of female workers aged 25 years old and above relative to the years of schooling of male workers in the same age bracket. Data on years of schooling are taken from the August 2014 version of the Barro-Lee Educational Attainment Dataset (http://www.barrolee.com/).

Work experience, most often proxied by actual age less estimated age at completion of schooling, can also affect earnings (see, for example, Mincer 1974). But, while most literature analyzing this relationship utilizes micro data, for example, population surveys matched or combined with longitudinal data on earnings or employment records, or labor force surveys that contain data on earnings and levels of education of respondents, measures of actual experience at the macro level are hard to estimate. For lack of a better measure, we used two proxy variables to capture potential work 
experience or the time spent in the labor force-the relative age of the work force and fertility rate. The relative age of the work force is calculated as the ratio of young workers aged 15-24 to workers aged 15-64. A higher ratio indicates a relatively young workforce; hence, work experience tends to be lower. A lower ratio indicates a relatively aging workforce; hence, higher experience. The gender disparity among young workers would be the ratio of female to male young workers. The fertility rate can also proxy for work experience as it shows women's lifetime work behavior. There is a great body of work that analyzes the inverse relationship between the fertility rate and female labor force participation (and earnings). Generally, the greater the number of children in a family, the greater the time spent by women on childbearing and child-rearing. More often than not, women are expected to drop out of the labor force earlier and more frequently than men. A higher fertility rate means lower or disrupted work experience as it indicates an early exit by female workers from the labor force. These indicators, however, tend to be biased in the sense that they do not capture work interruptions, continuous participation, or the quality of work experience.

We also examined the effect of increased participation by women in the labor force relative to men on the wage gap. While the direction seems to be from wage rate to participation rate (Fair 1971), in the sense that potential income creates a likely element of money illusion in the short run, female labor force participation can also affect gender wage gap, especially if most of them enter low-paying jobs or sectors.

\section{EMPIRICAL RESULTS}

\section{A. Full Sample Results}

Estimation bias can arise if unobserved individual characteristics which affect wages, such as motivation or ability, are correlated with the explanatory variables, such as work continuity. For example, a more intermittent worker with less motivation could earn less, if interruptions reduce remuneration.

Column (a) of Table 3 shows that, with the fixed effects estimator, only the labor force participation ratio turns out to be significant and negative. The result suggests that the wage gap widens as more female workers enter the labor market relative to male, possibly because female workers are generally paid low or have low entry rates. This result, however, may suffer from biased estimator as possible heteroskedasticity or endogeneity problems are not controlled for.

Heteroskedasticity can arise for various reasons such as variations in sample size by country or sample coverage. For example, in some countries, the wage data refers to those working in the private sector as a whole; while, in some, it refers only to those in the manufacturing sector or the industry sector as a whole, or in both industry and service sectors. Those working in the service sector may have greater variance around their conditional-mean earnings than those working in the industry sector, which is mostly comprised of manufacturing companies.

To test for the presence of heteroskedasticity in the fixed effect regression model, we run the Breusch-Pagan/Cook-Weisberg test for heteroskedasticity. The results rejected the null of constant variance and concluded the presence of heteroskedasticity. To address this, the model is fitted again using the feasible generalized least squares (FGLS) model. FGLS allows models with heteroskedasticity and autocorrelation between the error terms. Results after controlling for the heteroskedasticity using FGLS are not shown in this paper, as the results are virtually the same as the fixed effects model. The postestimation Wald test suggests, however, that the estimated coefficients are not significantly different from zero. Therefore, the FGLS does not seem to be a good estimator. 
Next, endogeneity issue is tackled. Controlling for endogeneity appears important both from theoretical and empirical considerations. The endogeneity becomes a problem if explanatory variables are not given exogenously but subject to an individual's decision and unobserved characteristics that create gap in productivity, preferences, and traits. For example, if women value job flexibility more than men they may choose to accept a lower wage job but with flexible hours. The impact on the wage rate is therefore likely to be estimated with bias when using simple estimators. However, existing studies that address the issue properly are limited. We test the hypothesis of number of years in schooling and the labor force participation ratio being endogenous, for example, to expected wage gap. In this paper, a panel two-stage least squares (2SLS) regression analysis is used with expected wages and region dummy as instrumental variables (IVs). ${ }^{7}$ Postestimation test results suggest that the gender ratio of the number of years in schooling is exogenous to the gender wage ratio in our sample. ${ }^{8}$ This is contrary to our prior that the decision on how much education one takes up may depend on his or her perception about the return on education. But this claim may be more applicable to higher education than primary education, which is more of an issue for developed countries.

Because of this, we will only show the estimation results, where the labor force participation rate is considered to be endogenous, and expected earnings and regional dummies are shown to be valid and strong instruments. Column (b) shows the 2SLS estimation results. In addition to the experience proxy variables and the labor force participation ratio, the gender ratios in each of the economic sectors, the macro-level factor, are also found to matter in accounting for the gender wage gap variations. More entry of female workers into the industry sector relative to male workers would widen the wage gap, while its effect is opposite for the agriculture sector. This is, to some extent, as expected and consistent with the existing literature. One of the explanations for this result in the industry sector may be the lower unionization rate of female workers, which leads to weaker bargaining power by female workers for higher pay (Blau and Kahn 2003). The negative effects entering to the service sector may be due to the underdeveloped sector offering low-paying jobs for female workers.

While the postestimation tests validate the choice of instrumental variables, and the estimation results appear intuitive, limitations remain. The expected wage gap and regional dummy were used as the IVs in the second 2SLS regression, and left out other important unobservable variables; hence, the estimates are likely to be mismeasured. Also, other variables such as proximity to schools, or parent's education that are likely to affect levels of education, are not available for the set of countries we looked at, hence, not modeled into the equation, increasing the degree of heteroskedasticity in the error process. To address the issue of unobserved heterogeneity and lack of instruments, we fit the model further using Lewbel's (2012) method.

Lewbel's technique allows the identification of structural parameters in regression models with endogenous or mismeasured regressors in the absence of traditional identifying information, such as external instruments or repeated measurements. A common feature in many models is when regressors are correlated with the error term due to an unobserved common factor. The greater the degree of heteroskedasticity in the error process, the higher will be the correlation of the generated instruments with the included endogenous variables. Unlike single-equation IV regression models, Lewbel's (2012) method can be applied: (i) when no external instruments are available, and/or (ii) to supplement external instruments to improve the efficiency of the IV estimator.

7 The expected wage is constructed as the wage gap of one period ahead, $t+1$.

8 Wooldridge's score test of exogeneity, F-statistics for joint significance, Cragg and Donald (1993) minimum eigenvalue test statistic, and Sargan's test of overidentifying restrictions were conducted. See Table 3. 


\section{Table 3: Regression Results for the Full Sample}

Dependent variable: Wage gap (W)

\begin{tabular}{|c|c|c|c|c|}
\hline Variables & $\begin{array}{l}\qquad(\mathrm{a}) \\
\text { Fixed Effects } \\
\text { Model (FE) }\end{array}$ & $\begin{array}{l}\text { (b) } \\
\text { Two-Stage Least } \\
\text { Squares Model } \\
\text { (2SLS) }\end{array}$ & \multicolumn{2}{|c|}{$\begin{array}{l}\text { (c) } \\
\text { Lewbel-Instrumental } \\
\text { Variable (IV) }\end{array}$} \\
\hline Endogenous variable & Not applicable & $\begin{array}{l}\text { Ratio of female to } \\
\text { male labor force } \\
\text { participation } \\
\text { (LFPRatioln) }\end{array}$ & \multicolumn{2}{|c|}{$\begin{array}{l}\text { Ratio of female to male labor force } \\
\text { participation } \\
\text { (LFPRatioln) }\end{array}$} \\
\hline Instrumental variables (IV) specified & Not applicable & $\begin{array}{l}\text { Expected wages } \\
\text { (F.w) and region } \\
\text { dummy }\end{array}$ & $\begin{array}{l}\text { Expected wages } \\
(\text { F.w) and region } \\
\text { dummy }\end{array}$ & No IV specified \\
\hline $\begin{array}{l}\text { Type of IV used or generated by } \\
\text { Lewbel IV }\end{array}$ & & & $\begin{array}{l}\text { Generated + } \\
\text { External } \\
\text { Instruments (or } \\
\text { above IV) }\end{array}$ & $\begin{array}{l}\text { Generated } \\
\text { Instruments only }\end{array}$ \\
\hline Dummy variable & Year & Year + country & Year & Year \\
\hline $\begin{array}{l}\text { Ratio of share of total female } \\
\text { employment working part time to } \\
\text { share of total male employment } \\
\text { working part time (PT) }\end{array}$ & $\begin{array}{l}-0.0101 \\
(0.0116)\end{array}$ & $\begin{array}{r}-0.0143 \\
(0.0168)\end{array}$ & $\begin{array}{l}-0.0273^{* * *} \\
(0.00990)\end{array}$ & $\begin{array}{l}-0.0243^{* *} \\
(0.00993)\end{array}$ \\
\hline $\begin{array}{l}\text { Ratio of share of female workers in } \\
\text { services to share of male workers in } \\
\text { services (servemployratioln) }\end{array}$ & $\begin{array}{r}0.0395 \\
(0.0664)\end{array}$ & $\begin{array}{r}-0.379^{* *} \\
(0.164)\end{array}$ & $\begin{array}{r}0.0772 \\
(0.0560)\end{array}$ & $\begin{array}{r}0.0474 \\
(0.0531)\end{array}$ \\
\hline $\begin{array}{l}\text { Ratio of share of female workers in } \\
\text { industry to share of male workers in } \\
\text { industry (indemployratioln) }\end{array}$ & $\begin{array}{r}-0.0163 \\
(0.0303)\end{array}$ & $\begin{array}{l}-0.136^{* *} \\
(0.0585)\end{array}$ & $\begin{array}{r}-0.0476^{* *} \\
(0.0234)\end{array}$ & $\begin{array}{r}-0.0555^{* *} \\
(0.0222)\end{array}$ \\
\hline $\begin{array}{l}\text { Ratio of share of female workers in } \\
\text { agriculture to share of male workers } \\
\text { in agriculture (agriemployratioln) }\end{array}$ & $\begin{array}{l}0.00564 \\
(0.0166)\end{array}$ & $\begin{array}{l}0.0408^{*} \\
(0.0214)\end{array}$ & $\begin{array}{r}0.000539 \\
(0.00905)\end{array}$ & $\begin{array}{r}0.00268 \\
(0.00889)\end{array}$ \\
\hline $\begin{array}{l}\text { Fertility rate (births per women) } \\
\text { (FERT) }\end{array}$ & $\begin{array}{l}-0.0368 \\
(0.0335)\end{array}$ & $\begin{array}{c}-0.283^{* * *} \\
(0.0831)\end{array}$ & $\begin{array}{r}-0.0320^{* *} \\
(0.0157)\end{array}$ & $\begin{array}{r}-0.0364^{* *} \\
(0.0151)\end{array}$ \\
\hline $\begin{array}{l}\text { Ratio of share of female workers } \\
\text { that are young to share of male } \\
\text { workers that are young (Ifagegap) }\end{array}$ & $\begin{array}{r}0.0141 \\
(0.0441) \\
\end{array}$ & $\begin{array}{r}-0.312^{* * *} \\
(0.120)\end{array}$ & $\begin{array}{l}-0.0238 \\
(0.0435)\end{array}$ & $\begin{array}{r}-0.0278 \\
(0.0403)\end{array}$ \\
\hline $\begin{array}{l}\text { Ratio of female labor force } \\
\text { participation rate to male labor force } \\
\text { participation rate (LFPRratioln) }\end{array}$ & $\begin{array}{l}-0.191^{* *} \\
(0.0837)\end{array}$ & $\begin{array}{r}-1.977^{* * *} \\
(0.536)\end{array}$ & $\begin{array}{r}-0.173 \\
(0.108) \\
\end{array}$ & $\begin{array}{r}-0.177 \\
(0.108) \\
\end{array}$ \\
\hline $\begin{array}{l}\text { Ratio of female to male years of } \\
\text { schooling (yrschln) }\end{array}$ & $\begin{array}{l}-0.128 \\
(0.114)\end{array}$ & $\begin{array}{l}-0.229 \\
(0.145)\end{array}$ & $\begin{array}{l}-0.0626 \\
(0.0673)\end{array}$ & $\begin{array}{r}-0.0393 \\
(0.0630)\end{array}$ \\
\hline Constant & $\begin{array}{c}-0.388^{* * *} \\
(0.0434)\end{array}$ & $\begin{array}{r}-0.498^{* * *} \\
(0.138)\end{array}$ & $\begin{array}{l}0.0278^{* * *} \\
(0.0108)\end{array}$ & $\begin{array}{l}0.0256^{* * *} \\
(0.00629)\end{array}$ \\
\hline Observations & 536 & 488 & 472 & 520 \\
\hline R-squared & 0.365 & 0.843 & 0.293 & 0.304 \\
\hline Root mean square error (RMSE) & & 0.0512 & 0.0287 & 0.02859 \\
\hline Number of ctryid4 & 53 & & & \\
\hline
\end{tabular}


Table 3 continued

\begin{tabular}{|c|c|c|c|c|}
\hline Variables & $\begin{array}{l}\text { (a) } \\
\text { Fixed Effects } \\
\text { Model (FE) }\end{array}$ & $\begin{array}{l}\text { (b) } \\
\text { Two-Stage Least } \\
\text { Squares Model } \\
(2 S L S)\end{array}$ & \multicolumn{2}{|c|}{$\begin{array}{l}\text { (c) } \\
\text { Lewbel-Instrumental } \\
\text { Variable (IV) }\end{array}$} \\
\hline \multicolumn{5}{|l|}{ Postestimation tests: } \\
\hline $\begin{array}{l}\text { a. Wooldridge's score test of } \\
\text { exogeneity }\end{array}$ & & $\begin{array}{l}\text { Reject null } \\
\text { (Ho: variables are } \\
\text { exogenous), at } \\
5 \% \text {, hence } \\
\text { endogenous }\end{array}$ & & \\
\hline b. F-statistics for joint significance & & $\begin{array}{l}\text { Robust }(F(1,414) \\
=16.7425 \\
\text { Prob }>F=0.0001\end{array}$ & & \\
\hline $\begin{array}{l}\text { c. Cragg and Donald (1993) } \\
\text { minimum eigenvalue test statistic }\end{array}$ & & $\begin{array}{l}\text { Minimum } \\
\text { eigenvalue } \\
\text { statistic = } 21.89 \text { (> } \\
\text { 10), hence IVs not } \\
\text { weak }\end{array}$ & & \\
\hline $\begin{array}{l}\text { d. Sargan's test of overidentifying } \\
\text { restrictions }\end{array}$ & & Just identified & & \\
\hline $\begin{array}{l}\text { e. Underidentification test } \\
\text { (Kleibergen-Paap rk Lagrange- } \\
\text { Multiplier (LM) statistic) }\end{array}$ & & & $\begin{array}{l}\text { Accept null (Ho: } \\
\text { the (excluded) } \\
\text { instruments are } \\
\text { not correlated } \\
\text { with the } \\
\text { endogenous } \\
\text { regressor). }\end{array}$ & $\begin{array}{l}\text { Accept null (Ho: } \\
\text { the (excluded) } \\
\text { instruments are } \\
\text { not correlated } \\
\text { with the } \\
\text { endogenous } \\
\text { regressor). }\end{array}$ \\
\hline $\begin{array}{l}\text { f. Weak identification test (Cragg- } \\
\text { Donald Wadd F Statistic). }\end{array}$ & & & $\begin{array}{l}\text { Minimum } \\
\text { Eigenvalue } \\
\text { statistic }=7.897 \text { (> } \\
6.22) \text {, hence IV } \\
\text { not weak at 20\% } \\
\text { maximal IV } \\
\text { relative bias. }\end{array}$ & $\begin{array}{l}\text { Minimum } \\
\text { Eigenvalue } \\
\text { statistic = } 7.897 \text { (> } \\
6.24), \text { hence IV } \\
\text { not weak at 20\% } \\
\text { maximal IV } \\
\text { relative bias. }\end{array}$ \\
\hline $\begin{array}{l}\text { g. Overidentification test (Hansen J } \\
\text { statistic). }\end{array}$ & & & $\begin{array}{l}\text { Reject null (Ho: } \\
\text { the (excluded) } \\
\text { instruments - } \\
\text { when more in } \\
\text { number than the } \\
\text { endogenous } \\
\text { regressors - are } \\
\text { coherent with }\end{array}$ & $\begin{array}{l}\text { Accept null (Ho: } \\
\text { The (excluded) } \\
\text { instruments - } \\
\text { when more in } \\
\text { number than the } \\
\text { endogenous } \\
\text { regressors - are } \\
\text { coherent with }\end{array}$ \\
\hline
\end{tabular}

Notes: All variables are in log terms. All variables in columns c and d, using the Lewbel (2012) method, were standardized with a mean zero and standard deviation of 1 prior to estimation. Robust standard errors in parentheses: ${ }^{* * *} p<0.01,{ }^{* *} p<0.05,{ }^{*} p<0.1$.

Sources: Staff calculations using data from the World Bank, World Development Indicators online database. http://databank.worldbank.org/data/home.aspx; International Labour Organization. Global Wage Report 2012. http://www.ilo.org; Barro, Robert, and Jong-Wha Lee. 2013. "A New Data Set of Educational Attainment in the World, 1950-2010.” Journal of Development Economics 104: 184-98 (August 2014 Update). http://www.barrolee.com; Philippine Statistics Authority, Labor Force Survey; and DGBAS, Manpower Survey Results. 
The results, with the robust option, are in Table 3, columns (c) and (d). The data is standardized prior to the estimations so the country fixed effects are controlled for. The results in column (c) are with the additional instrument, and those in column (d) are the estimation results using only the internally generated instruments. The Hansen J statistic for overidentification accepted the null, giving us the confidence that the instruments set are appropriate. The estimation results show the indicators to be more precisely estimated now as the standard errors are much smaller using Lewbel's (2012) method.

When we use the Lewbel estimator that can control for the heterogeneity, heteroskedasticity, and endogeneity issues at the same time, the employment in the service and agriculture sectors and the young worker ratio are no longer significant indicating some mismeasurement. Only three variables, the ratios of part-time workers, ratio of employment in the industry sector, and fertility rate, turned out to be robust and are consistently significant in explaining the gender wage gap. This result indicates that simultaneously controlling for the endogeneity and heteroskedasticity is crucial, which could not have been done by the three estimators used previously. Relatively more female in part-time position in the industry sector and having more births would widen the wage gap. The results are generally consistent with what we expect.

The comparison of the results of the four different estimators confirms that controlling for mismeasurement and biases is crucial in understanding the factors driving the gender wage gap. The results can identify the driving factors only after the methodological issues are properly controlled for. The results suggest that both micro- and macro-level factors are important in explaining the cross-country variations in gender wage gap; namely, the ratio of industry sector employment and the fertility ratio.

\section{B. Does Level of Development Matter?}

We then divide the sample into developed and developing countries to examine if the factors affecting the gender wage gap vary across different income groups or the levels of development. The results are intuitive and interesting. The Lewbel (2012) estimation results are in Table 4. Consistent with the results for the whole sample, Table 4 shows that relatively more female workers in the industry sector widen the gender wage gap regardless of the income levels of the country though the effect appears larger in developed country subsample (column a). The fertility rate, on the other hand, seems to matter only in the developing country group (column b). In the developing country group, the higher the average birth rate, the lower the average income is of female workers relative to male workers, but this is not evident with the developed country sample.

In addition, there are findings that were not evident in the whole sample results. In the developed country sample, both relatively more young female workers and also higher female labor force participation ratio would lead to higher gender pay gap. Given that the pay gap is mostly negative, i.e., female workers are paid less, more entry of female workers means closing of this pay gap. This is probably due to some high-skilled high-paid professions that female workers take up in developed countries, such as in the areas of financial and legal sectors. The service sector as a whole is not found to be significant, probably because the sector includes lower-paying jobs, such as in retail or medical care sectors.

On the other hand, in the developing country group, relatively more female workers in the labor market would lead to wider wage gap. This is consistent with the negative coefficient for fertility rate, which causes a break in female workers' career and shorter work experience. Another notable finding is the negative impact of the years of schooling. For the developing country group, more years spent in school does not seem to help the girls to close the pay gap. This could be due to overeducated workers in jobs that offer very low returns to education and that underwent little technological change

(see, for example, Mehta et.al. 2011); skills mismatch; or job polarization induced by technological changes that eliminate jobs in the middle of the wage distribution (Mehta et al. 2009). 


\section{Table 4: Regression Results: Developed versus Developing Economies}

Dependent variable: Wage gap $(W)$

\begin{tabular}{|c|c|c|}
\hline \multirow[b]{2}{*}{ Variables } & (a) & (b) \\
\hline & \multicolumn{2}{|c|}{ Lewbel-Instrumental Variable (IV) } \\
\hline \multirow{3}{*}{ Endogenous variable } & Developed & Developing \\
\hline & $\begin{array}{l}\text { Ratio of female to male labor } \\
\text { force participation (LFPRratioln) }\end{array}$ & $\begin{array}{l}\text { Ratio of female to male labor } \\
\text { force participation (LFPRratioln) }\end{array}$ \\
\hline & No IV specified & No IV specified \\
\hline Type of IV used & Generated instruments only & Generated Instruments only \\
\hline Dummy variable & Year & Year \\
\hline $\begin{array}{l}\text { Ratio of share of total female employment working part time } \\
\text { to share of total male employment working part time (PT) }\end{array}$ & $\begin{array}{l}-0.0235 \\
(0.0148)\end{array}$ & $\begin{array}{r}-0.00674 \\
(0.0117)\end{array}$ \\
\hline $\begin{array}{l}\text { Ratio of share of female workers in services to share of } \\
\text { male workers in services (servemployratioln) }\end{array}$ & $\begin{array}{r}-0.0195 \\
(0.0942)\end{array}$ & $\begin{array}{r}0.149^{* *} \\
(0.0682)\end{array}$ \\
\hline $\begin{array}{l}\text { Ratio of share of female workers in industry to share of } \\
\text { male workers in industry (indemployratioln) }\end{array}$ & $\begin{array}{l}-0.137^{* * *} \\
(0.0316)\end{array}$ & $\begin{array}{r}-0.0555^{* *} \\
(0.0273)\end{array}$ \\
\hline $\begin{array}{l}\text { Ratio of share of female workers in agriculture to share } \\
\text { of male workers in agriculture (agriemployratioln) }\end{array}$ & $\begin{array}{r}0.000425 \\
(0.0181)\end{array}$ & $\begin{array}{r}0.0124 \\
(0.0102)\end{array}$ \\
\hline $\begin{array}{l}\text { Fertility rate (births per women) } \\
\text { (FERT) }\end{array}$ & $\begin{array}{r}0.0204 \\
(0.0236) \\
\end{array}$ & $\begin{array}{r}-0.0685^{* * *} \\
(0.0198) \\
\end{array}$ \\
\hline $\begin{array}{l}\text { Ratio of share of female workers that are young to share } \\
\text { of male workers that are young (Ifagegapln) }\end{array}$ & $\begin{array}{l}0.137^{* * *} \\
(0.0488)\end{array}$ & $\begin{array}{r}-0.0741 \\
(0.0575)\end{array}$ \\
\hline $\begin{array}{l}\text { Ratio of female labor force participation rate to male } \\
\text { labor force participation rate (LFPRratioln) }\end{array}$ & $\begin{array}{r}0.332^{* * *} \\
(0.123) \\
\end{array}$ & $\begin{array}{r}-0.343^{* * *} \\
(0.105) \\
\end{array}$ \\
\hline $\begin{array}{l}\text { Ratio of female to male years of schooling } \\
(y r s c h l n)\end{array}$ & $\begin{array}{l}-0.207^{* * *} \\
(0.0792)\end{array}$ & $\begin{array}{l}-0.0131 \\
(0.105)\end{array}$ \\
\hline Constant & $\begin{array}{r}0.00533 \\
(0.00618) \\
\end{array}$ & $\begin{array}{l}0.0272^{* *} \\
(0.0108)\end{array}$ \\
\hline Observations & 269 & 251 \\
\hline R-squared & 0.4458 & 0.287 \\
\hline Root mean square error (RMSE) & 0.0209 & 0.03363 \\
\hline
\end{tabular}

\section{Postestimation tests:}

a. Underidentification test (Kleibergen-Paap rk Lagrange-Multiplier (LM) statistic). b. Weak identification test (Cragg-Donald Wadd F
statistic).

c. Overidentification test (Hansen J statistic).
Accept null (Ho: The (excluded) instruments are not correlated with the endogenous regressor).

Minimum Eigenvalue statistic < 4.43, hence weak IV.

Accept null (Ho: The (excluded) instruments - when more in number than the endogenous regressors - are coherent with each other).
Accept null (Ho: The (excluded) instruments are not correlated with the endogenous regressor).

Minimum Eigenvalue statistic $=$ 5.009 (>4.43), hence not weak at $30 \%$ maximal IV relative bias).

Accept null (Ho: If the (excluded) instruments - when more in number than the endogenous regressors - are coherent with each other).

Notes: All variables are in log terms and are standardized with a mean zero and standard deviation of 1 prior to estimation. Developed economies here refers to high-income economies of the Organisation for Economic Co-operation and Development, based on the July 2016 definition and groupings by the World Bank. https://datahelpdesk.worldbank.org/knowledgebase/articles/906519-world-bank-country-and-lending-groups In this paper, the Republic of Korea, is classified as a developing economy based on the definition of the Asian Development Bank. Robust standard errors in parentheses: ${ }^{* *} p<0.01,{ }^{* *} p<0.05,{ }^{*} p<0.1$.

Sources: Staff calculations using data from the World Bank, World Development Indicators online database.

http://databank.worldbank.org/data/home.aspx; International Labour Organization. Global Wage Report 2012. http://www.ilo.org; Barro, Robert, and Jong-Wha Lee. 2013. “A New Data Set of Educational Attainment in the World, 1950-2010.” Journal of Development Economics 104: 184-98 (August 2014 Update). http://www.barrolee.com; Philippine Statistics Authority, Labor Force Survey; and DGBAS, Manpower Survey Results. 


\section{CONCLUSION AND POLICY IMPLICATIONS}

This paper examines the gender wage gap using average wage data at the country level for a sample of 53 economies spanning over the period 1995-2010. It contributes to the literature by covering both developed and developing economies, and examining both microeconomic and macroeconomic factors affecting the gender wage gap. Robust estimators such as Lewbel (2012) are used to address empirical issues to uncover unbiased findings-factors affecting the wage gap after addressing heterogeneity and endogeneity issues. The unbiased estimators suggest that both micro and macro factors affect the gender wage gap, and that in particular, a higher female share in the industry sector is a significant factor dampening the female workers' wage below their male counterparts. This result is robust and holds both for developed and developing economies; the result is consistent with the existing studies. One of the reasons for this to happen is often unorganized labor unions for female workers in low-technology industry sector, which is usually the first place for female workers to find their jobs either moving from the agriculture sector or from household work. Male workers tend to be better placed to negotiate their pay with the employers than their female counterparts.

Meanwhile, having more children would widen the gender wage gap as expected, but this result can only be found in developing countries while it is not the case for developed countries. Further, for developing countries, we find that more labor market participation or more years of schooling by women alone would not lead to narrow the gender wage gap. These results point to issues related to industry structure and job quality. Higher-paying jobs should be created through developing the service sector, for example, in these economies. Otherwise, more years in school would not narrow the pay gap. In developed countries, on the other hand, more labor force participation by women does seem to narrow the gender wage gap, probably due to female workers entering the labor market to take up higher-paying service sector jobs, which tend to be available only in selected developed economies. 


\section{APPENDIX: DEFINITION OF VARIABLES AND THEIR DATA SOURCES}

\begin{tabular}{|c|c|c|}
\hline Variable & Definition/Calculations & Source \\
\hline $\begin{array}{l}\text { Ratio of female to male } \\
\text { average nominal gross } \\
\text { monthly wages (Wage } \\
\text { gap) }\left(W_{t}\right)\end{array}$ & $\begin{array}{l}\text { Calculations: } \\
\text { Monthly wages are derived either from annual, biannual, quarterly, } \\
\text { weekly, daily, or hourly data. From annual data, wage numbers are } \\
\text { divided by 12, and from quarterly, by } 3 \text {. Weekly wage data are converted } \\
\text { by multiplying it with 52/12, while daily wage data are multiplied by } 5 \text { or } \\
6 \text {, depending on the country, then by } 52 / 12 \text {. Hourly wage data are } \\
\text { converted by first multiplying it with hours worked per week, which } \\
\text { range from } 35 \text { to } 48 \text { hours per week, then by 52/12. } \\
\text { For some countries, the aggregation depends on available data. In cases } \\
\text { where there are only one or two data points per year, the monthly wage is } \\
\text { based on the available data or is derived as the average of two data points. In } \\
\text { cases where there are two overlapping similar wage series, the data are spliced } \\
\text { by applying the growth rate of one series to the preferred or longer series. } \\
\text { As most countries have incomplete data sets, all wage data used are } \\
\text { standardized to the degree possible to allow comparability across } \\
\text { countries and regions. Nominal monthly wage data reported in index } \\
\text { terms are excluded from the analysis. For countries that report more than } \\
\text { one series of wage data, preference is given to those sourced from } \\
\text { national sources. If unavailable, those from other sources, such as the } \\
\text { International Labour Organization (ILO) and Eurostat, in the case of } \\
\text { European Union member and candidate countries, are used. The data } \\
\text { generally covers all types of workers and sectors. For some countries, the } \\
\text { data refer to those working in the private sector as a whole; while for } \\
\text { some, it refers only to those in the manufacturing sector, industry sector, } \\
\text { or in both industry and service sectors. In terms of firm size, most } \\
\text { countries did not report it. But those that did, the firm size is mostly } 10 \\
\text { employees up. For countries that gave the same response or category for } \\
\text { employment cover, sector, and firm size, for all wages series provided, } \\
\text { preference is given to the longer series. } \\
\text { The wage generally pertains to those aged } 15 \text { and above, but for some } \\
\text { countries, this includes those aged } 12-14 \text {. }\end{array}$ & $\begin{array}{l}\text { ILO. Global Wage Report } \\
\text { 2012. } \\
\text { http://www.ilo.org/public } \\
\text { /english/download/globa } \\
\text { I-wage-report-2012/ilo- } \\
\text { global-wage-database- } \\
\text { 2012.xls. }\end{array}$ \\
\hline $\begin{array}{l}\text { Ratio of share of total } \\
\text { female employment } \\
\text { working part time to } \\
\text { share of total male } \\
\text { employment working } \\
\text { part time }\left(P T_{t}\right)\end{array}$ & $\begin{array}{l}\text { This indicator pertains to the number of individuals whose total working } \\
\text { hours is less than "full time," as a proportion of total employment by } \\
\text { gender. For countries with one missing data point, such as Argentina, } \\
\text { Ecuador, Panama, Paraguay, and Uruguay, the part-time ratios are } \\
\text { estimated using the average of the ratios at } t-1 \text { and } t+1 \text {. }\end{array}$ & $\begin{array}{l}\text { ILO. Key Indicators of the } \\
\text { Labour Market, 8th } \\
\text { edition }\end{array}$ \\
\hline $\begin{array}{l}\text { Sector employment } \\
\left(S E C_{i, t}\right) \text { : } \\
\text { Ratio of share of female } \\
\text { workers in services to } \\
\text { share of male workers in } \\
\text { services } \\
\text { (servemployratioln) } \\
\text { Ratio of share of female } \\
\text { workers in industry to } \\
\text { share of male workers in } \\
\text { industry } \\
\text { (indemployratioln) }\end{array}$ & $\begin{array}{l}\text { This is the ratio of female to male employment in the agriculture, } \\
\text { service, or industry sectors (calculated as the share of female } \\
\text { employment in a specific sector to total female employment) in the } \\
\text { same sector (calculated as the share of male employment in a specific } \\
\text { sector to total male employment). For countries with one missing data } \\
\text { point, such as Argentina, Ecuador, Panama, Paraguay, and Uruguay, the } \\
\text { sector employment ratios are estimated using the average of the ratios } \\
\text { at } t-1 \text { and } t+1 \text {. }\end{array}$ & $\begin{array}{l}\text { ILO. Key Indicators of the } \\
\text { Labour Market, 8th } \\
\text { edition }\end{array}$ \\
\hline
\end{tabular}




\begin{tabular}{|c|c|c|}
\hline Variable & Definition/Calculations & Source \\
\hline \multicolumn{3}{|l|}{$\begin{array}{l}\text { Ratio of share of female } \\
\text { workers in agriculture to } \\
\text { share of male workers in } \\
\text { agriculture } \\
\text { (agriemployratioln) }\end{array}$} \\
\hline $\begin{array}{l}\text { Education Gap proxy } \\
\left(E D_{t}\right) \text { : } \\
\text { Ratio of female to male } \\
\text { average years of } \\
\text { schooling (yrschln) }\end{array}$ & $\begin{array}{l}\text { This is the ratio of female to male average years of schooling attained by } \\
\text { those aged } 25 \text { years and above. } \\
\text { Calculations: } \\
\text { The original data set is presented in } 5 \text {-year intervals. The annual series are } \\
\text { extrapolated using the compounded annual growth rate approach. For a } \\
\text { more detailed discussion about the estimation methodology, see Barro } \\
\text { and Lee (2013). } \\
\text { http://www.sciencedirect.com/science/article/pii/S0304387812000855. }\end{array}$ & $\begin{array}{l}\text { Barro-Lee Educational } \\
\text { Attainment Dataset. } \\
\text { http://www.barrolee.com/ } \\
\text { (August } 2014 \text { Update) }\end{array}$ \\
\hline $\begin{array}{l}\text { Experience Proxy }\left(E x_{t}\right) 1: \\
\text { Fertility rate (FERT) }\end{array}$ & $\begin{array}{l}\text { This refers to total births per woman. Total fertility rate represents the } \\
\text { number of children that would be born to a woman if she were to live to } \\
\text { the end of her childbearing years and bear children in accordance with } \\
\text { age-specific fertility rates of the specified year. }\end{array}$ & $\begin{array}{l}\text { World Development } \\
\text { Indicators. } \\
\text { http://data.worldbank.or } \\
\text { g/indicator/SE.PRM.NIN } \\
\text { T.ZS. }\end{array}$ \\
\hline $\begin{array}{l}\text { Experience Proxy }\left(E x_{t}\right) 2 \text { : } \\
\text { Ratio of share of female } \\
\text { workers that are young } \\
\text { to share of male workers } \\
\text { that are young } \\
\text { (lfagegapln) }\end{array}$ & $\begin{array}{l}\text { This refers to the ratio of young female workers (computed as the ratio } \\
\text { of female labor force participation rate [female LFPR] of those in 15-24 } \\
\text { age bracket to the female LFPR aged 15-64), to young male workers } \\
\text { (computed as the ratio of male labor force participation rate [male } \\
\text { LFPR] of those aged 15-24 to male LFPR aged 15-64). }\end{array}$ & $\begin{array}{l}\text { ILO. Key Indicators of the } \\
\text { Labour Market, 8th } \\
\text { edition }\end{array}$ \\
\hline $\begin{array}{l}\text { Ratio of female labor } \\
\text { force participation rate } \\
\text { to male labor force } \\
\text { participation rate } \\
\text { (LFPRratioln) }\end{array}$ & $\begin{array}{l}\text { Proportion of a country's working-age population that engages actively } \\
\text { in the labor market, either by working or looking for work }\end{array}$ & $\begin{array}{l}\text { ILO. Key Indicators of the } \\
\text { Labour Market, 8th } \\
\text { edition }\end{array}$ \\
\hline
\end{tabular}

Note: All variables are in log of the ratios, except fertility, which pertains only to the log of total births per woman.

Sources: World Bank, World Development Indicators online database. http://databank.worldbank.org/data/home.aspx; International Labour Organization. Global Wage Report 2012. http://www.ilo.org; Barro, Robert, and Jong-Wha Lee. 2013. “A New Data Set of Educational Attainment in the World, 1950-2010.” Journal of Development Economics 104: 184-98 (August 2014 Update). http://www.barrolee.com; Philippine Statistics Authority, Labor Force Survey; and DGBAS, Manpower Survey Results. 


\section{REFERENCES}

Barón, Juan D., and Deborah A. Cobb-Clark. 2008. "Occupational Segregation and the Gender Wage Gap in Private and Public Sector Employment: A Distributional Analysis." Institute for the Study of Labor. IZA Discussion Paper No. 3562.

Barro, Robert, and Jong-Wha Lee. 2010. "A New Data Set of Educational Attainment in the World, 1950-2010." Journal of Development Economics 104: 184-98 (August 2014 Update). http://www.barrolee.com/.

Beblo, Miram, Denis Beninger, Anja Heinze, and François Laisney. 2003. "Methodological Issues Related to the Analysis of Gender Gaps in Employment, Earnings and Career Progression." A project carried out for the European Commission, Employment and Social Affairs DG.

Becker, Gary S. 1985. "Human Capital, Effort, and the Sexual Division Labor." Journal of Labor Economics 3 (1): 33-58.

Blackaby, David, Alison L. Booth, and Jeff Frank. 2005. "Outside Offers and the Gender Pay Gap: Empirical Evidence from the UK Academic Labour Market.” Economic Journal 115 (501): 81107.

Blau, Francine D., and Lawrence M. Kahn. 2000. "Gender Differences in Pay." Journal of Economic Perspectives 14 (4): 75-99.

2003. "Understanding International Differences in the Gender Pay Gap.” Journal of Labor Economics 21 (1): 106-44.

2006. “The U.S. Gender Pay Gap in the 1990s: Slowing Convergence.” ILR Review 60 (1): 4566.

_ 2007. “The Gender Pay Gap.” The Economists' Voice Vol. 4: Issue 4, Article 5.

Blinder, Alan S. 1973. "Wage Discrimination: Reduced Form and Structural Estimates." The Journal of Human Resources 8 (4): 436-55.

Chichilnisky, Graciela, and Elisabeth H. Frederiksen. 2008. "An Equilibrium Analysis of the Gender Wage Gap.” International Labor Review 147 (4): 297-320.

The Conference Board. Total Economy Database. https://www.conferenceboard.org/data/economydatabase/index.cfm?id=27762 (accessed April 2015).

Cragg, John G., and Stephen Donald. 1993. "Testing Identifiability and Specification in Instrumental Variable Models." Econometric Theory 9 (2): 222-40.

Datta Gupta, Nabanita, Ronald Oaxaca, and Nina Smith. 2006. "Swimming Upstream, Floating Downstream: Comparing Women's Relative Wage Progress in the United States and Denmark." Industrial and Labor Relations Review 59 (2): 243-66. 
Edin, Per-Anders, and Katarina Richardson. 2002. "Swimming with the Tide: Solidary Wage Policy and the Gender Earnings Gap.” The Scandinavian Journal of Economics 104 (1): 49-67.

Fair, Ray. 1971. "Labor Force Participation, Wage Rates, and Money Illusion.” The Review of Economics and Statistics 53 (2): 164-68. http://www.jstor.org/stable/1925712.

Frederiksen, Elisabeth H. 2006. "An Equilibrium Analysis of the Gender Wage Gap.” Economic Policy Research Unit Working Paper No. 2006-08. Department of Economics, University of Copenhagen. http://www.econ.ku.dk/eprn_epru/Workings_Papers/wp-06-08.pdf.

Gayle, George-Levi, and Limor Golan. 2011. "Estimating a Dynamic Adverse-Selection Model: LabourForce Experience and the Changing Gender Earnings Gap 1968-1997." Review of Economic Studies 79 (1): 227-67. https://doi.org/10.1093/restud/rdr019.

Ginther, Donna K. 2004. "Why Women Earn Less: Economic Explanations for the Gender Salary Gap in Science." Awis Magazine 33 (1): 6-10.

Hegewisch, Ariane, and Heidi Hartmann. 2014. "Occupational Segregation and the Gender Wage Gap: A Job Half Done." Washington DC: Institute for Women's Policy Research. https://www.dol.gov/wb/resources/occupational_segregation_and_wage_gap.pdf.

International Labour Organization (ILO). 2012. Global Wage Report. Geneva. http://www.ilo.org/public/english/download/global-wage-report-2012/ilo-global-wagedatabase-2012.xIs.

- 2014. Key Indicators of the Labour Market, 8th edition. Geneva. http://kilm.ilo.org/2011/download/kilmcompleteEN.pdf.

Lewbel, Arthur. 2012. "Using Heteroskedasticity to Identify and Estimate Mismeasured and Endogenous Regressor Models." Journal of Business and Economic Statistics 30 (1): 67-80.

Matteazzi, Eleonora, Ariane Pailhé, and Anne Solaz. 2013. "Does Part-Time Employment Widen the Gender Wage Gap? Evidence from Twelve European Countries." Society for the Study of Economic Inequality. ECINEQ Working Paper 2013 - 293 (March). http://www.ecineq.org/milano/WP/ECINEQ2013-293.pdf.

Mehta, Aashish, Jesus Felipe, Pilipinas Quising, and Shiela Camingue. 2009. "Where Have All the Educated Workers Gone? Education and Structural Transformation in Three Asian Economies." Santa Barbara: Center for Global and International Studies, University of California-Santa Barbara. https://escholarship.org/content/qt9n06h70f/qt9n06h70f.pdf?nosplash=b9f7d343b7a383aca 566801e7048686a.

2011. "Overeducation in Developing Economies: How Can We Test for It, and What Does It Mean?" Economics of Education Review 30 (6): 1334-47.

Meyersson Milgrom, Eva M., Trond Petersen, and Vemund Snartland. 2001. "Equal Pay for Equal Work? Evidence from Sweden and a Comparison with Norway and the US." Scandinavian Journal of Economics 103 (4): 559-83. 
Mincer, Jacob A. 1974. "Schooling and Earnings." In Schooling, Experience and Earnings, 41-63. Cambridge, MA: National Bureau of Economic Research.

Oaxaca, Ronald. 1973. "Male-Female Wage Differentials in Urban Labor Markets." International Economic Review 14 (3): 693-709.

Olivetti, Claudia, and Barbara Petrongolo. 2014. "Gender Gaps across Countries and Skills: Demand, Supply and the Industry Structure." Review of Economic Dynamics 17 (4): 842-59.

Organisation for Economic Co-operation and Development (OECD). 2002. "Women at Work: Who Are They and How Are They Faring?” In OECD Employment Outlook, 61-125. Paris.

Rosholm, Michael, and Nina Smith. 1996. "The Danish Gender Wage Gap in the 1980s: A Panel Data Study.” Oxford Economic Papers 48 (2): 254-79.

Waldfogel, Jane. 1998. "The Family Gap for Young Women in the United States and Britain: Can Maternity Leave Make a Difference?” Journal of Labor Economics 16 (3): 505-45.

Weichselbaumer, Doris, and Rudolf Winter-Ebmer. 2005. "A Meta-Analysis of the International Gender Wage Gap.” Journal of Economic Surveys 19 (3): 479-511.

Winder, Katie L. 2004. "Reconsidering the Motherhood Wage Penalty." Mimeo. Baltimore: John Hopkins University. 


\section{Gender Pay Gap: A Macro Perspective}

Gender wage inequality remains a persistent problem in both developing and developed countries. This paper explores this phenomenon using a unique data set that covers 53 economies spanning the period 1995-2010. Robust estimators show different factors influence the wage gap at different stages of development. Closing gender gaps in labor force participation - an important factor in developing economies - and education does little to equalize wages in developing economies. Higher-paying jobs should be created by expanding the service sector in these economies.

\section{About the Asian Development Bank}

ADB's vision is an Asia and Pacific region free of poverty. Its mission is to help its developing member countries reduce poverty and improve the quality of life of their people. Despite the region's many successes, it remains home to a large share of the world's poor. ADB is committed to reducing poverty through inclusive economic growth, environmentally sustainable growth, and regional integration.

Based in Manila, ADB is owned by 67 members, including 48 from the region. Its main instruments for helping its developing member countries are policy dialogue, loans, equity investments, guarantees, grants, and technical assistance. 